\title{
BIMBINGAN ANAK BERKONFLIK DENGAN HUKUM OLEH BALAI PEMASYARAKATAN BANDUNG DI TINJAU DARI RELASI PERTOLONGAN
}

\author{
Oleh: \\ Fitri Nuryanti Sahlan, Budhi Wibhawa, \& Maulana Irfan \\ Email:
}

Fitrysahlan@gmail.com

\begin{abstract}
ABSTRAK
Anak adalah generasi muda yang penting untuk di bangun potensinya demi terciptanya cita-cita bangsa. . Kenakalan anak sering disebut dengan "juvenile delinquency," yang diartikan dengan anak cacat sosial. Kenakalan anak dapat berujung pada sebuah kondisi dimana anak berada dalam sebuah pelanggaran hukum negara. Anak yang berkonflik dengan hukum (ABH) merupakan anak yang disangka atau dituduh telah melanggar undang-undang hukum pidana. Pidana adalah hukuman yang dijatuhkan seseorang yang terbukti secara sah dan meyakinkan melakukan tindak pidana. Anak yang berkonflik dengan hukum yang berusia 12 hingga 18 tahun, ada yang berujung pada hukuman penahanan. Anak memiliki hak sebagai manusia berupa hak asasi manusia. Banyak faktor yang memungkinkan anak melakukan tindak pidana dan berkahir dalam tahanan. Kondisi tersebut memungkinkan untuk anak mengalami tekanan baik fisik maupun mental. Selain itu stigma buruk yang tercipta dalam masyarakat akan menjadi hambatan anak untuk siap kembali menjalani hidup di masyarakat setelah menjalani tahanan. Masalah tersebut yang menyadarkan betapa pentingnya adanya pekerja sosial dalam sistem peradilan anak.

Setelah adanya penahanan, anak yang melakukan tindak pidana akan di adili dengan sistem peradilan anak. Dalam proses peradilan anak, anak berkonflik dengan hukum (ABH ) akan di bina melalui bimbingan pemasyarakatan. Balai pemasyarakatan akan melakukan pendampingan dan pengawasan terhadap proses peradilan. Hubungan yang akan di bangun oleh balai pemasyarakatan tidak hanya dengan anak berkonflik dengan hukum $(\mathrm{ABH})$ namun juga dengan keluarga dan masyarakat. Hubungan -hubungan yang dijalin merupakan relasi yang sengaja di bentuk oleh pihak-pihak yang berkepentingan. Relasi tersebut diupayakan untuk terciptanya harapan anak berkonflik dengan hukum $(\mathrm{ABH})$ dapat diterima kembali secara baik oleh masyarakat. Relasi yang bertujuan untuk keberlangsungan masa depan anak berkonflik dengan hukum dapat termasuk kedalam sebuah relasi yang dilakukan oleh pekerja sosial yakni relasi pertolongan.
\end{abstract}

Kata kunci : Anak Berkonflik Dengan Hukum, System Peradilan Anak, Bimbingan

Pemasyarakatan, Relasi Pertolongan.

\section{PENDAHULUAN}

Dalam era modern saat ini, Peningkatan tekhnologi mempengaruhi perkembangan kehidupan bermasyarakat. Kemajuan tekhnologi dewasa ini secara tidak langsung memicu lahirnya beragam jenis kejahatan dalam masyarakat. Anak adalah salah satu 
korban dari kejahatan-kejahatan yang tercipta berdasarkan kemajuan kehidupan masyarakat. Anak adalah generasi muda yang penting untuk di bangun potensinya demi terciptanya cita-cita bangsa. Usia yang masih dalam tahap perkembangan membuat anak masih memiliki banyak peluang dalam melakukan pembelajaran. Pengembangan potensi anak merupakan hak mendasar anak yang harus didapatkan. Dalam penjelasan undang-undang Republik Indonesia 11 Tahun 2012 tentang Sistem Peradilan Pidana Anak disebutkan:

Anak adalah bagian yang tidak terpisahkan dari keberlangsungan hidup manusia dan keberlangsungan sebuah bangsa dan Negara. Dalam konstitusi Indonesia, anak memiliki peran strategis yang secara tegas dinyatakan bahwa negara menjamin hak setiap anak atas kelangsungan hidup, tumbuh, dan berkembang serta atas perlindungan dari kekerasan dan diskriminasi. Oleh karena itu, kepentingan terbaik bagi anak patut dihayati sebagai kepentingan terbaik bagi kelangsungan hidup umat manusia. Konsekuensi dari ketentuan Pasal 28B Undang-undang Dasar Negara Republik Indonesia Tahun 1945 perlu ditindak lanjuti dengan membuat kebijakan pemerintah yang bertujuan melindungi anak. (Dalam jurnal Dr. I Made Sepud, Sh, Mh : hal.1)

Kejahatan yang terjadi saat ini beragam jenisnya, baik yang dilakukan oleh orang dewasa maupun anak. Kenakalan anak sering disebut dengan "juvenile delinquency," yang diartikan dengan anak cacat sosial. Menurut Kartini Kartono menegaskan bahwa delikuensi selalu mempunyai konotasi serangan, pelanggaran, kejahatan, dan keganasan yang dilakukan oleh anak-anak muda di bawah usia 22 (dua puluh dua) tahun. Berdasarkan data anak yang berhadapan dengan hukum dari situs kementerian pemberdayaan perempuan dan perlindungan anak Republik Indonesia pada tahun 2008 (dalam Dewi dan Fatahillah A. Syukur, 2011: 21) terdapat 41.778 anak yang berhadapan dengan hukum di Indonesia. Pidana adalah hukuman yang dijatuhkan seseorang yang terbukti secara sah dan meyakinkan melakukan tindak pidana. UU No.
3 Tahun 1997, menentukan bahwa terhadap anak nakal hanya dapat dijatuhkan pidana atau tindakan (Pasal 22). Pidana pokok terdiri dari pidana penjara, pidana kurungan, pidana denda, dan pidana pengawasan (pasal 23 ayat (2) UU No.3 Tahun 1997). Jumlah anak yang berkonflik dengan hukum memang tidak sedikit, hampir pada setiap provinsi memiliki sejumlah anak yang berkonflik dengan hukum. Contoh Kenakalan anak yang pernah terjadi sampai pada peradilan adalah kasus pencurian sandal oleh AAL.

Perlindungan anak adalah segala usaha yang dilakukan untuk menciptakan kondisi agar setiap anak dapat melaksanakan hak dan kewajibannya demi perkembangan dan pertumbuhan anak secara wajar baik fisik, mental, dan sosial. Perlindungan anak merupakan perwujudan adanya keadilan Dalam suatu masyarakat, dengan demikian di usahakan dalam berbagai bidang kehidupan benrnegara dan dan bermasyarakat. Kegiatan perlindungan anak membawa akibat hukum, bak dalam kaitannya dengan hukum tertulis maupun hukum tidak tertulis. Hukum merupakan jaminan bagi kegiatan perlindungan anak.

Perlindungan anak merupakan upaya untuk memenuhi hak-hak anak. Berjuang sendiri untuk mendapatkan hak adalah hal yang belum dapat dilakukan oleh anak. Pada hakikatnya anak tidak dapat melindungi dirinya sendiri dari berbagai macam tindakan yang menimbulkan kerugian baik fisik, mental, dan sosial dalam bebagai bidang kehidupan. Hukum adalah rangkaian peraturan-peraturan mengenai tingkah laku orang-orang sebagai anggota-angota masyarakat, sedangkan tujuannya adalah untuk mengadakan keselamatan, kebahagiaan, dan tata tertib masyarakat. Menurut Arif Gosita mengatakan bahwa hukum perlindungan anak adalah hukum (tertulis maupun tidak tertulis) yang menjamin anak benar-benar dapat melaksanakan hak dan kewajibannya. 
Perlindungan anak menyangkut berbagai aspek kehidupan dan penghidupan , agar anak benar-benar dapat tumbuh dan berkembang dengan wajar sesuai dengan hak asasinya.

Kehidupan manusia dipengaruhi oleh keadaan dan situasi, begitu juga di alami oleh anakanak yang menjalani pidana. Dengan usia yang masih dalam tahap perkembangan fisik, mental, dan sosial, anak membutuhkan cara khusus untuk dibina. Tujuan pembinaan anak yang berkonflik dengan hukum atau yang telah resmi ditahan adalah agar anak memahami halhal yang diperbolehkan dan hal-hal yang dilarang, sehingga tidak mengulangi kesalahannya. Peradilan anak berbeda dengan peradilan orang dewasa. Peraturan yang diperuntukkan untuk mengadili anak harus berdasarkan perlindungan anak. Peradilan tersebut tidak hanya bersifat melindungi anak namun juga membina anak untuk tidak melakukan kembali pelanggaran hukum. Berikut asas-asas yang membedakan pengadilan anak dan dewasa :

1. Pembatasan umur

Orang yang dapat disidangkan dalam acara penngadilan anak secara liminatif, yaitu minimum berumur 8 tahun sampai umur 18 tahun (pasal 1 butir 1 dan pasal 4 ayat 1 UU no. 3 tahun 1997) .

2. Ruang lingkup masalah dibatasi

Masalah yang diperiksa di sidang pengadilan anak hanyalah menyangkut perkara anak nakal saja.

3. Ditangani pejabat khusus

Pejabat khusus yang di maksud adalah penyidik anak, penuntut umum anak, dan hakim anak.

4. Peran pembimbing kemasyaraktan

Undang-undang no.3 tahun 1997 mengakui peran pembimbing kemasyarakatan, pekerja sosial, dan pekerja sosial relawan.

5. Suasana pemeriksaan dan kekeluargaan
Seluruh pejabat khusus tidak memakai toga karena berasaskan kekeluargaan.

6. Keharusan splitsing

7. Acara pemeriksaan tertutup

8. Diperiksa oleh hakim tunggal

9. Masa penahanan lebih singkat

Asas ini berlandaskan pada tujuan bahwa tidak akan berpengaruh besar terhadap fisik, mental, dan sosial anak.

10. Hukuman perkembangan lebih ringan

Peringanan hukuman telah dijelaskan dalam 22-23 uu no.3 tahun 1997). Hukuman maksimal terhadap anak adalah 10 tahun.

Asas tersebut sangat berpengaruh dalam perlindungan anak yang berkonflik dengan hukum. Dalam perannya lembaga hukum dan Hak asasi manusia dapat melaksanakan fungsinya dengan baik. Balai pemasyarakatan dalam melaksanakan fungsi dan perannya terdapat sebuah usaha pertolongan. Pada tahap penyidikan dan pengadilan, anak yang berkonflik dengan hukum $(\mathrm{ABH})$ akan didampingi oleh pihak balai pemasyarakatan. Selain itu pada masa anak mendapat keringanan pihak balai pemasyarakatan melakukan pengawasan dan pendampingan. Dalam waktu yang bukan pembentukkan kembali mental anak terdapat usaha-usaha untuk mencegah terjadinya ketidak adilan terhadap anak. Proses tersebut dapat dilihat sebagai proses interaksi guna menghasilkan keterikatan yang baik menuju penyelesaian masalah hukum bersama. Dalam praktek pekerja sosial interaksi yang dibuat berupa relasi pertolongan. Balai pemasyarakatan adalah lembaga yang memungkinkan menggunakan metoda tersebut. Maka kasus dapat dilihat dari bagaimana pihak balai pemasyarakatan dalam melakukan pertolongan terhadap anak yang berkonflik dengan hukum. 
Relasi Pertolongan Dalam Bimbingan Pemasyarakatan

Masalah delikuensi atau kenakalan anak menjadi masalah yang komplek saat ini. kemajuan kehidupan bermasyarakat menyadarkan betapa pentingnya hukum. Kenakalan anak terjadi karena beberapa faktor seperti pergaulan dan kesalahan persepsi. Menurut Romli Atmasasmita dalam Wagiati Soetodjo (Wagiati Soetodjo, 2006 :17), motivasi intrinsik dan ekstrinsik dari kenakalan anak :

1. Yang termasuk motivasi intrinsik dari pada kenakalan anak-anak adalah : a. Faktor intelegentia;b. Faktor usia; c. Faktor kelamin; d. Faktor kedudukan anak dalam keluarga.

2. Yang termasuk motivasi ekstrinsik adalah : a. Faktor rumah tangga; b. Faktor pendidikan dan sekolah; c. Faktor pergaulan anak; d. Faktor mass media.

Berbagai faktor tersebut memungkinkan bagi anak untuk melakukan kenakalan dan kegiatan kriminal yang dapat membuat mereka terpaksa berhadapan dengan hukum dan sistem peradilan. Anak yang melakukan tindak pidana ini bisa disebut pula dengan anak yang berkonflik dengan hukum.

Relasi pertolongan adalah interaksi yang terjadi antara pekerja sosial dan klien dimana dalam hal ini klien di buat merasa nyaman sehingga penyelesaian masalah dapat dilakukan dengan baik. Menurut ichwan muis relasi pertolongan adalah :

"suatu proses saling mengikatkan dan melibatkan diri antara satu atau lebih yang dilakukan secara sadar dan terencana dikenakan dengan tujuan untuk memperoleh stabilitas dan memiliki pola simbolik dan tatap muka"

Dalam proses peradilan anak pendampingan akan diberi fasilitas untuk konsultasi anak. Dalam tahap penyidikan anak akan bertatap muka secara langsung dengan pihak yang bertugas. Dalam penjelasan Umum Undangundang Nomor 11 Tahun2012 menyatakan bahwa Mengingat ciri dan sifat yang khas pada Anak dan demi perlindungan terhadap Anak, perkara Anak yang berhadapan dengan hukum wajib disidangkan di pengadilan pidana Anak yang berada di Iingkungan peradilan umum. Proses peradilan perkara Anak sejak ditangkap, ditahan, dan diadili pembinaannya wajib dilakukan oleh pejabat khusus yang memahami masalah Anak.

Pekerjaan sosial dalam melakukan proses pertolongan tidak lepas dari komunikasi dan relasi yang merupakan konsep dasar dalam proses pertolongan. Dalam proses pertolongan setiap pekerja sosial apabila menangani klien tidak lepas dari aktivitas interaksi seperti komunikasi sebagai suatu proses penyampaian pikiran atau perasaan ke orang lain sehingga menimbulkan respon. Selain pekerja sosial, beberapa profesi lain pun menggunakkan komunikasi. Dalam bimbingan pemasyarakatan tidak akan terlepas dari komunikasi antar pihak terkait seperti pihak lembaga dan klien. Proses peradilan terdapat proses bimbingan yang dapat di tinjau dari relasi pertolongan.

Relasi pertolongan memiliki karakteristik sebagai berikut:

1. Berorientasi pada pemenuhan kebutuhan klien, bukan kebutuhan pekerja sosial.

Fellix Biestek dalam bukunya "the case work relationship" menyatakan bahwa kebutuhan dasar manusia dalam melakukan relasi :

a. Ingin diperlakukan sebagai individu yang unik

b. Mengekspresikan perasaan-perasaan

c. Memperoleh simpati atas masalah atau kegagalan yang dialami.

d. Tidak dipersalahkan atau dihakimi

e. Dikenal dan dihargai sebagai manusia yang bermartabat

f. Diakui haknya untuk memilih dan menentukan keputusan sendiri 


\section{g. Ingin dihargai keputusannya}

2. Bersifat mendorong dan menambah energy

3. Secara sosial bersifat integratif dan inklusif

Berdasarkan Integratif relasi mengarah pada kesepakatan sedangkan inklusif mengarah kepada kesetiakawanan dan kegotong royongan. Orientasi relasi mengarah pada kesepakatan bukan pada perbedaan, sehingga relasi menawarkan keakraban, saling menghargai, menerima dan saling mengakui nilai dan identitas masing-masing.

4. Bersifat transaksional yaitu merupakan komunikasi dua arah dan harus ada partisipasi.

5. Relasi yang murni, jujur dan realitas.

6. Bersifat komplementaris

Secara teoritis, sekurang-kurangnya ada dua syarat bagi interaksi sosial, yaitu terjadinya kontak sosial dan komunikasi. Terjadinya suatu kontak sosial tidaklah semata-mata tergantung dari tindakan, tetapi juga tergantung kepada adanya tanggapan terhadap tindakan tersebut. Sedangkan aspek terpenting dari komunikasi adalah bila seseorang memberikan tafsiran pada sesuatu atau perikelakuan orang lain (Suyanto dan Septi Ariadi, 2004: 16).

Kemampuan berkomunikasi adalah salah satu keahlian pekerja sosial. Komunikasi dibutuhkan dalam praktek mikro yaitu ketika memulai hubungan dengan klien dan kemudian untuk bekerja pada tingkat individu. Relationsip help, dapat dibangun melalui komunikasi yang baik dan hangat. Dalam penyidikan seorang pekerja sosial harus memiliki empati dimana hal ini membantu pekerja sosial dalam proses wawancara.

Dalam proses pengadilan, pekerja sosial dapat menjadi mediator ataupun broker.
Pihak-pihak terkait merupakan penyediaan dari balai pemasyarakatan. Dengan ilmu pekerja sosial kelompok relasi pertolongan dalam tahap ini dapat dilakukan melalui mediasi. Dalam pengadilan anak ,ketentuan anak yang masuk tahanan sangat detail naun tanpa bantuan actor mediasi kesalahan dalam keputusan dapat saja terjadi.

Ruang Iingkup perlindungan hukum bagi anak mencakup: (1) perlindungan terhadap kebebasan anak; (2) perlindungan terhadap hak asasi anak, dan (3) perlindungan hukum terhadap semua kepentingan anak yang berkaitan dengan kesejahteraan.

Secara filosofis anak adalah bagian dari generasi muda yang dijadikan sebagai asset Negara. Anak yang berkonflik dengan hukum masih memiliki masa depan yang panjang. Kepentingan hak anak sangat perlu untuk dilindungi. Hukum indonesia telah detail dalam melindungi anak dari system yang salah. Penanganan terkait anak yang berkonflik dengan hukum menjadi sangat penting untuk diperhatikan kembali implementasinya. Dalam peradilan anak, pengadilan restoratif sangat dibutuhkan. Dewasa ini keadilan restoratif berangkat dari kebutuhan anak yang berkonflik dengan hukum. Anak membutuhkan pengadilan yang dapat membuat anak kembali menemukan kepercayaan diri untuk menjalani masa depan yang lebih baik.

Dengan Perlindungan terhadap anak yang berkonflik dengan hukum dalam penyelesaiannya melibatkan semua pihak yang meliputi peran orang tua, keluarga, masyarakat, pemerintah, lembaga negara lainnya yang berkewajiban dan bertanggungjawab dalam peningkatan kesejahteraan anak, serta perlindungan khusus terhadap anak yang bersangkutan. Menurut Tony F. Marshall, Keadilan restoratif adalah suatu proses dimana semua pihak yang terlibat dalam suatu tindak pidana tertentu bersamasama memecahkan masalah bagaimana menangani akibat di masa yang akan datang.

Proses pertolongan pekerja sosial adalah suatu tahapan kerja atau perubahan 
yang digunakan untuk melakukan suatu upaya perubahan berencana dalam rangka membantu klien memecahkan masalah. Proses tersebut berdasarkan kepada suatu kerangka waktu yang telah ditentukan dalam suatu perencanaan yang matang. Situasi pertolongan dalam pekerjaan sosial merupakan situasi yang terdiri dari sekumpulan orang-orang yang terlibat interaksi serta berfokus pada suatu periode waktu tertentu selama proses pertolongan atau proses pelayanan.

Dalam pengadilan sering didapati adanya ketidakadilan akibat kepentingan beberapa pihak. Ketika balai pemasyarakatan melakukan tindakan maka relasi pertolongan kemungkinan akan ada dalam proses pertolongan anak dalam pengadilan. Selain itu dalam proses penyidikan dan bimbingan pemasyarakatan relasi pertolongan kemungkinan akan dilakukan secara terencana. Proses pertolongan ini sebagai upaya pemenuhan hak anak sebagai manusia yang memiliki hak asasi manusia.

\section{DAFTAR PUSTAKA}

Maldini Gustom. 2008. Perlindungan Hukum Terhadap Anak Dalam System Peradilan Di Indonesia. Bandung ;PT Refika Aditama.
Arthur E.Jongsman, jr.2001, The Social Work And Human Service Treatmen.plan Wiley.

Adami Chazawi, 2005, Pelajaran Hukum Pidana 2,PT Raja Grafindo Persada, Jakarta.

Barbara F Okun, Cetakan III ; Effective Helping Interviewing And Conseling Tehniques, Brooks/ Cole Publishing Company. California.

Budhi Wibawa, Santoso T Rahardjo, Meilany Budiarti. 2010 , Dasar-dasar Pekerjaan Sosial, Widya Padjadjaran, Bandung.

Moh. Nazir, 1998. Metode Penelitian, Jakarta. Ghalia Jakarta

Septiawan Santana K, 2010, cetakan II. Menulis Ilmiah Metodologi Penelitian Kualitatif. Jakarta. Yayasan Obor Indonesia

Marshall, Tony F. 1999. Retorative Justice a n Overview . London : Home Office, Information \& Publications Group

Soetodjo, Wagiati, 2006. Hukum Pidana Anak. Bandung : PT. Refika Aditama

Dr. I Made Sepud, Sh, Mh, "Perlindungan Hukum Terhadap Pelaku Tindak Pidana Anak Melalui Diversi Dalam Sistem peradilan Pidana Anak Di Indonesia”, 2012. 